International Journal of Language Education

Volume 5, Number 3, 2021, pp. 165-179

ISSN: $2548-8457$ (Print) 2548-8465 (Online)

Doi: https://doi.org/10.26858/ijole.v5i3.16506

\title{
The Inhibition and Communication Approaches of Local Languages Learning Among Millennials
}

\author{
Dasrun Hidayat \\ Adhirajasa Reswara Sanjaya University, Indonesia \\ Email:dasrun@ars.ac.id \\ Gartika Rahmasari \\ Adhirajasa Reswara Sanjaya University, Indonesia \\ Email: gartika.rahmasari@gmail.com \\ Darajat Wibawa \\ Islamic State University of Sunan Gunung Djati, Indonesia \\ Email: darajatwibawa@uinsgd.ac.id
}

Received: 08 December 2020

Reviewed: 1 May 2021-1 August 2021

Accepted: 1 October 2021

\begin{abstract}
Local languages which are also referred as mother tongue should be attached to every child as individual. The re-orientation of language due to global influences should not mean forgetting the local language. Globalization and traditions can run simultaneously so that millennial generations are not only proficient in foreign languages, but also understand in using their local languages. This is a communication and culture research. The purpose of this study was to determine the millennials assumptions about local languages and the teaching approaches needed. An integrated teaching approach is needed so that it can restore the millennials' interest and confidence in speaking their local languages. This research used a descriptive qualitative method with interview techniques, involving millennial generation from Jakarta, West Java and Lampung Provinces. The results of the study show that some of the millennials can speak their local languages but not as active speakers. There are two major obstacles that prevent the millennials to speak their local languages, namely internal and external factors. Internal factor that prevents them from speaking their local languages is family, and the external factors include peers, environment and technology. To encourage the use of local language, the government has issued Regional Regulations (PERDA) so that local languages can be used by daily life such as in schools. In addition, equality communication model can be used in teaching local languages, that include seriousness, openness, acceptance, and flexible teaching This approach is supported by binding local government regulations that require the use of local languages in a variety of contexts, including the language of instruction in education.
\end{abstract}

Keywords: equality communication model; globalization; local languages; millennial; teaching

\section{Introduction}

Indonesia is a country with the second largest local languages in the world after Papua New Guinea (Tondo, 2009). This is in line with the number of tribes that reaches more than 1,300 tribes 
(Hidayat \& Hafiar, 2019). The multi-ethnicity gives birth to numerous cultures. Hence, this situation leads to changes or the creation of new languages, or the preference to use national language, which is Indonesian, on a daily basis than local languages, which can lead to the extinction of local languages. This is in line with the previous research that multi-ethnicity condition will result in language shift, which is a permanent change in one's language preference for daily life particularly due to migration, or language change, which is the change in language during a period as stated by Kridalaksana (Tondo, 2009).

The shifts in understanding and the use of language can be also caused by people's reorientation driven by global factors. For example, parents prioritize their children to learn foreign language, hence the children cannot speak their local language. This happens because parents think the globalization era requires their children to master foreign language, and not their local language. However, previous research results mentioned that based on its position and function as foreign language in Indonesia, English language is not a language that competes with other languages, such as local languages, particularly with the country as well as national language, Indonesian language. English is taught in educational institution, not as the means to deliver education (Agustin, 2011).

The existence of foreign languages is actually inevitable in the midst of globalization era. Every area, particularly urban area, tends to have metropolitan style, namely style that orientates toward modernization including in adopting language. It was even mentioned in previous studies that foreign languages are considered as direct means of communication and connecting between nations and languages that open the opportunities for the emergence of new language or foreign language (Pastika, 2012). Therefore, precaution act must be done so that local languages will not extinct, and one will not be trapped in disadvantageous situations.

Several research results that have been discussed affirm the position of local language as basic language. Furthermore, local languages are able to alter situation in every area to be better. On the other side, Indonesian language has function and position as national language that is taught in educational institutions. Also, foreign languages function as additional knowledge for children. Therefore, other than those contexts, local languages are still used as daily means of communication.

Providing teaching and understanding about the position of local languages certainly can help overcome the shift in people's orientation towards local languages. One of the reality shifts in the orientation of regional languages occurs in millennial generation. Currently, they are more fluent in foreign languages and prefer to speak Indonesian than local languages. In almost every context, from the family, friends, school, they do not use local languages. This condition occurs due to various factors, one of which is due to the weak function of family education. For this reason, the local language teaching system must be instilled as early as possible, beginning with the family environment. The system is expected to be able to foster millennial interest in learning the local language. In addition, it also encourages the level of confidence of millennials to use their language starting from the smallest environments, such as family and playmates.

Based on the explanation in the previous section, this article focuses on discussing local language teaching systems and their implications for millennial generation communication. Some aspects that were explored included the level of knowledge and understanding of millennial generation towards regional languages, factors influencing the knowledge and use of local languages, and the approach used in teaching local languages among millennials. It is hoped that some of the aspects in question can answer as well as become solutions about the position of regional languages in the midst of modern society. The research question of this study was how 
millennial assumptions about local languages and the teaching approaches needed. An integrated teaching approach is needed so that it can restore millennial interest and confidence in local languages. This study aims to determine the level of knowledge and use of local languages. The research also wants to find a solution to the right approach in instilling the interests of millennial generation using their respective local languages.

\section{Literature review}

A holistic approach in introducing regional languages as a communication tool that influences development in each region is required for local language teaching in the multi-ethnic Indonesia. Moreover, language is a tool to get to know the culture around and other cultures (Samovar et al., 2010). This is what underlies the importance of this study to be conducted. Researchers assess that the reduction or even extinction of several local languages will continue to happen if there is no attempt to stop it.

The family and local government are expected to be able to reopen the regional language horizons that are now starting to be uprooted from its roots. This effort may hopefully be able to compensate for the flow of global information so that the language spectrum of the millennial generation will not be carried away by global currents. In addition, the collaboration between the two very influential parties is expected to be able to contribute to interest, as well as the actions of millennial generation to restore local languages as the main languages and communication tools in various contexts.

Millennial generation is also referred to as generation $\mathrm{Y}$, the generation born in the range of the eighties to the nineties. Millennial is a generation that is identical with a lifestyle that likes to use technology, high curiosity, and curiosity (Hidayat, 2018). Millennial generation cultural values usually adhere to technology as a lifestyle (Shofiyyah et al., 2019). Millennial is also identical with the era or period marked by the development of communication technology. Millennial chooses internet-based technology tools in sending, searching and reading information (Habibi, 2018). The interest of millennial generation toward changes and technological advances is quite large, especially the use of internet-based telecommunications media such as smartphones for various purposes, for example smartphones that are used to facilitate access to information (Sari, 2019). This is consistent with previous studies that millennial generation is characterized by the flow of technological developments such as gadgets, technology that has given birth to instant communication behavior (Anwar \& Salim, 2018). The characteristics inherent in the millennial generation at the same time prove that their orientation is different from the previous generation, namely generation $\mathrm{X}$ (Hidayat, 2018). Generation $\mathrm{X}$ is a generation that has cultural values such as being able to adapt, work hard, be independent, and be able to accept change.

The lifestyle of millennial generation is always accompanied by instant, procedural dislikes, and prefers those with modern style. The lifestyle is influenced by global culture. This phenomenon occurs as a result of the current of globalization that can no longer be dammed (Sutijono \& Farid, 2018). The habit of liking this instant thing has also been found in previous studies, that the millennial generation is the type of a person who prefers practical things (Barni, 2019). The generation that wants more convenience, and every instant thing (Shofiyyah et al., 2019). Lifestyle as an effect of global culture ultimately drives millennials to "dislike" traditional things like traditional food, and include traditional or regional languages. Most of the millennial generations are lazy to learn and use regional languages or their mother tongue.

It is important for millennial generation to learn, understand, and use their local languages because local languages are one aspect of social communication that can drive a change or 
development. Almost every region has its own local language, and the language is used as an approach in introducing its culture. There are many ways that are done and each region has its own strategy in applying the local language. For example, in Solo city there is a culture of Jagongan that is chatting together while relaxing. Jagongan can occur in coffee shops, wedding events, or in food stalls. The result is not only as a transfer of knowledge but also as a real discussion of public space (Vera \& Wihardi, 2012). Originally as a public space, the tradition of jagongan is able to be a place for local people to actualize the use of local languages.

Local languages are also very closely related to cultural activities in each region. Even regional languages become a communication tool that is believed to be able to provide success for each cultural activity. For example, Sedekah Buka Kebun in South Sumatra, Subak in Bali, Bate Waes in Manggarai, Ritual Pemurnian Desa (Village Purification Rites) in Kediri, Muang Jongdi Bangka Belitung, Mana'e dan Seke in North Sulawesi, and Kanuri Blang in Aceh (Maifianti et al., 2014). The same position and function of tradition is also found in Lampung called Butayuh (Hidayat et al., 2018). All of these cultural traditions or activities use local languages as a communication tool. Local languages are believed to be able to connect messages between one another.

Local language is usually taught to children as their first language, or known as mother tongue. If parents have certain ethnic status, then ideally the first language introduced to children is the local language of their parents (Arsanti, 2014). Getting used to using the local language requires a supportive environment from the family to the playmate environment. Family and playmates are able to build motivation to learn language, eliminate shyness when using language, build self-confidence, and build self-esteem (Humaera, 2015). The inhibitions that often prevent local languages from being used is the occurrence of cross-cultural marriages, making it difficult to determine which mother tongue they introduce to their children. In fact, these multicultural conditions require people to often use Indonesian (Indriati, 2015). Learning local languages means preserving, passing on by using them. Languages that can be maintained are written and readable languages, including regional languages that must be maintained as local identities (Rustipa, 2013). Introducing local languages can be through local government policies such as the education system by requiring the use of local languages in the school environment, increasing references, and having collaborative teachers in providing learning (Akello \& Timmerman, 2017).

Regional languages as mother tongue should be able to be learned, understood, and practiced by every child. However, in reality, knowledge and understanding begin to decrease, and the use of mother tongue or regional languages also begin to be abandoned. This of course will encourage the extinction of regional languages in the archipelago. This is line with research results which state that Language Center has found and classified as many as 756 local languages in Indonesia, but currently only 652 exist. This means that there are several regional languages that are extinct (Indira, et al., 2018). This data is similar to data issued by Language of The World (2005) that states that in Indonesia there are 742 languages, 737 of which are languages that are still alive or are still used by speakers (Tondo, 2009). Summer Institute of Linguistics (SIL) states that there are several local languages with a great amount of speakers, namely Javanese language (75.200.000 speakers), Sundanese language (27.000.000 speakers), Malay language (20.000.000 speakers), Maduranese language (13.694.000 speakers), Minangkabau language (6.500.000 speakers), Bataknese language (5.150.000 speakers), Bugis language (4.000.000 speakers), Balinese language (3.800.000 speakers), Acehnese language (3.000.000 speakers), Sasak language (2.100.000 speakers), Makassarese language (1.600.000 speakers), Lampung language (1.500.000 speakers) and Rejang language (1.000.000 speakers) (Tondo, 2009). 


\section{Research method}

This is a qualitative descriptive study, which is a study that focuses on describing in-depth and systematic description of research results. Qualitative descriptive also intends to describe the relationship between the results with the relevant concepts and theories (Denzin \& Lincoln, 2009). Qualitative descriptive in the context of this paper intends to describe the results and the findings of the fields related to local language teaching method and its implication for the communication of millennial generation.

To get the expected results, researchers used data collection techniques through interviews. Data retrieval was done at data sources that involved millennial generation. They were chosen by purposive sampling with criteria as millennial generation or born between the $80 \mathrm{~s}$ and $90 \mathrm{~s}$. In addition, millennials also consist of various tribes so that they have different regional languages. Establishing sampling criteria aims so that selected informants were according to predetermined research needs (Mohammad et al., 2016). Initially, there were 54 informants consisting of students from Lampung Province, Jakarta, and West Java Province. Informants from Lampung were taken from Lampung University (UNILA) and State Islamic University (UIN) of Raden Intan Lampung. Next, informants from Jakarta were taken from Jakarta State University (UNJ) and Bina Sarana Informatics University of Jakarta. Finally, informants from West Java were taken from Indonesian Education University (UPI) Bandung, Telkom University Bandung, University of Informatics and Business (UNIBI) Bandung, Adhirajasa Reswara Sanjaya University, and BSI University, Jakarta. However, there were only 11 active informants who responded to both online and direct interviews. Therefore, the data presented in the finding section was taken from 11 informants from different universities.

Table 1. Profiles of Research Informants

\begin{tabular}{lll}
\hline Informant Code & \multicolumn{1}{c}{ University } & Parents Ethnicity \\
\hline I-1 & State Islamic University (UIN) of Raden Intan Lampung & Lampung, Jawa \\
\hline I-2 & Lampung University (UNILA) & Lampung \\
\hline I-3 & Jakarta State University (UNJ) & Betawi \\
\hline I-4 & Bina Sarana Informatics University, Jakarta & Betawi, Jawa \\
\hline I-5 & Indonesian Education University (UPI), Bandung & Sunda \\
\hline I-6 & Telkom University, Bandung & Betawi \\
\hline I-7 & University of Informatics and Business (UNIBI) & Jawa \\
\hline I-8 & Adhirajasa Reswara Sanjaya University & Sunda \\
\hline I-9 & BSI University, Jakarta & Betawi \\
I-10 & Telkom University, Bandung & Dayak \\
I-11 & State Islamic University (UIN) of Raden Intan Lampung & Jawa, Lampung \\
\hline
\end{tabular}

Source: Research Result Data

The data analysis technique used is the analysis that refers to the stages of data collection in the form of interviews. The first stage of data construction is intended to reduce the data from interviews. Researchers at this stage conducted the data selection by reducing data that is considered not in accordance with the objectives of the study. The next stage is the second data construction or data display. Researchers studied then categorized the resulting data according to the theme needed to answer each research question. Data display can be in the form of tables, graphs, etc. which will then be described in the results section of the study. The final stage is the construction of a third data or making data conclusions. At this stage the researcher analyzed the main points of the findings contained in the results of the study (Hidayat et al., 2018). Analysis 
was conducted to answer each research question. Analysis can be strengthened by using existing and relevant theories to explain research findings in the form of concepts or theories.

\section{Results and discussion}

This part describes the finding results of the field as well as discusses or analyzes the findings. The findings include the level of knowledge and understanding of millennial generation towards their local languages. Other parts also describe the results related to factors that underlie the reasons why millennial generation does not use local language as a communication tool. Then, it also explains solutions or offers from millennial generation on the local language teaching approach model through the equality communication approach, as well as millennial actions to use local language again. The following section describes parts of findings and results on the local language teaching model and its implication for millennial generation.

Findings of research results include the inhibition faced by the millennials in using their indigenous languages, the enforcement of regulations as a disciplinary solution in learning and using regional languages, and equality approach as a strategy in learning regional languages among the millennials. Here is the explanation.

Family as an inhibiting factor in learning and using local languages

Based on interviews with informants, it can be classified that there are two factors that inhibit informants in learning and using local languages, namely internal and external factors. Internal factor includes family.

Family with inter-ethnicity marriage inhibits the use of regional language if not introducing their indigenous languages and using Indonesian language instead. This is stated by an informant I-1 from Universitas Islam Negeri (UIN) Raden Intan Lampung City, that "My mother is a Lampung native; my father is Javanese. Maybe that's the reason why my parents don't speak their native languages and speak Indonesian as the uniting language" (Informant interview on 7/08/2019). This is similar to the statement of an informant I-6 from Telkom University who said that "Nowadays, it's rare for parents to get used to speak local language to communicate at home, maybe it's because the environment doesn't use local language as well" (Informant interview on 12/08/2019). Informant I-10 admitted that he cannot communicate using local language actively because their parents don't habituate the use of their indigenous language even though both of them are Dayak tribe (Informant interview on 13/08/2019).

In addition, Informant I-8 from Adhirajasa Reswara Senjaya University also admitted that he is reluctant to speak local language because his parents don't tell him so. "How should I say, I can't speak my local language actively because my parents are not speaking it, that's why I don't speak it, but actually I understand when people speak (local language) (Informant interview on 10/08/2019). Informant I-5 from Universitas Pendidikan Indonesia had different experience regarding local language habituation in the family environment: "My parents are Sundanese and at home they use Sundanese language, and I also speak Sundanese actively" (Informant interview on 9/08/2019). This experience can be used as an evidence that the family is the smallest cultural unit in introducing, teaching and habituating the use of local language. 
Table 2. Internal Factors Inhibiting the learning of Local Languages

\begin{tabular}{|c|c|c|}
\hline Informant & Origin & Statements \\
\hline I-1 & $\begin{array}{l}\text { Universitas Islam Negeri (UIN) } \\
\text { Raden Intan Lampung City }\end{array}$ & $\begin{array}{l}\text { Parents didn't get used to use local languages because } \\
\text { they have different ethnicities, Lampung and Java }\end{array}$ \\
\hline $\mathrm{I}-6$ & Telkom University & Local language is not used in family environment \\
\hline $\mathrm{I}-10$ & Telkom University & $\begin{array}{l}\text { Parents didn't speak local language even though both } \\
\text { are from Dayak Tribe }\end{array}$ \\
\hline $\mathrm{I}-8$ & $\begin{array}{l}\text { Adhirajasa Reswara Seniaxa } \\
\text { University }\end{array}$ & There is no habituation from parents \\
\hline $\mathrm{I}-5$ & $\begin{array}{l}\text { Universitas } \\
\text { Indonesia }\end{array}$ & $\begin{array}{l}\text { Parents usually speak local language so that I speak it } \\
\text { actively }\end{array}$ \\
\hline
\end{tabular}

Source: Research Result

This is measured from the communication behavior in the family that has never been accustomed to local languages, whereas parents should be used as role models for children in language. The parents of millennials are educated parents so parents should provide positive examples for each child (Indriati, 2015), (Shofiyyah et al., 2019). This includes getting used to and fostering local language culture values in the family environment.

The lack of teaching local language in the immediate environment that is family is of course very unfortunate. The nuclear family environments should be the main foundation of millennial generation to study. Even the family is positioned as the first institution of millennial generation to know culture, including language (Jandt, 2013). Millennials still hold that the family is a very important pillar of their lives (Shofiyyah et al., 2019). In addition, the family can also be used as a strategy to introduce more about the culture of the region. Parental participation in teaching local languages can also build positive personality of millennial generation. Even previous studies found that the language of the region that is used actively can form a strong personality so that children are easy to adapt, and easily accepted in every environment (Laila, 2016). This is in line with the characteristics of millennial generation that is eager to learn interactively through teamwork, collaboration and group thinking (Shofiyyah et al., 2019). Therefore, millennials are actually very open to learn and use local language if there are invitation as well as provisions in the family so that they can instill the values of local languages.

Other factor why millennials does not receive local language teaching directly from their parents is because it is due to ethnic differences between fathers and mothers. There are interethnic marriages or, in other word, cultural integration through marriages (Hidayat et al., 2017). The picture of the impact of cultural integration is also reinforced by previous findings that multiethnic conditions will cause language shifts, i.e. constant changes in one's language choices for everyday needs (Tondo, 2009). Cultural integration does indeed often occur in multi-ethnic areas that creates confusion for children in finding their cultural identity. As a result, local language as one of the identities in the family is no longer spoken.

Peers and technology as external factors inhibiting the learning and the use of local languages

The shift in the use of local languages is also influenced by playmate factors. The results of the study mentioned that the majority of millennials are not fluent in using their local language because no one is using the local language environment. Even for their daily use, they use Indonesian. Acknowledged by the informants, they found it difficult to find groups of playmates who still retained local languages. Instead, they prefer to use Indonesian. Besides being not fluent in regional languages, other reasons are due to ethnic diversity among playmates. 
The outside environment of friends also rarely uses regional languages, maybe because the ethnic groups are different so it's better to use Indonesian (Informant I-8 interview on 10/08/2019). The confession of the informant from the Adhirajasa Reswara Sanjaya University was also strengthened by the statement of the informant I-9 from the University of BSI that his friends speak Indonesian, and when they meet, it was an unwritten agreement that they only used Indonesian. (Interview informant date 06/08/2019).

Communication technology also affects how the millennials communicate. For example, for daily communication they prefer to use chatting application and use Indonesian language while chatting. This is stated by an informant I-3 the State University of Jakarta that "we often chat through WhatsApp and it is safer to use Indonesian language when chatting so there will be no misunderstanding (Informant interview on 5/08/2019). This is in line with a previous study which mentions that millennial generation is identical with instant communication behavior or shifts to things that are informal and deemed easy, one of which is the use of communication technology (Barni, 2019).

Millennial generation also recognizes that there is a lack of knowledge and use of local languages due to communication technology, such as smartphones. Technology can accelerate the extinction of regional languages. This is stated by an informant 1-7 from UNIBI Bandung that "Technology has a big effect on the millennial's lack of interest in learning regional languages because more time is spent playing than learning regional languages (Informant interview on 13/08/2019). This is similar to opinion of an informant from the Informatics and Business University was also acknowledged by the informant I-2 from Lampung University (UNILA), feeling that there was no time to learn the regional language because it had been used up to play smartphones with friends.

Table 3. Peers and Technology as External Factors Inhibiting the use of regional language

\begin{tabular}{|c|c|c|}
\hline Informant & Origin & Statement \\
\hline $\mathrm{I}-8$ & $\begin{array}{l}\text { Adhirajasa Reswara Seniaxa } \\
\text { University }\end{array}$ & Peers don't use local language \\
\hline I-9 & University of BSI & Speak Indonesian like my friends \\
\hline $\mathrm{I}-3$ & Jakarta State University (UNJ) & $\begin{array}{l}\text { Chatting with friends in social media using Indonesian } \\
\text { language }\end{array}$ \\
\hline I-7 & $\begin{array}{l}\text { University of Informatics and } \\
\text { Business (UNIBI) }\end{array}$ & $\begin{array}{l}\text { There is no time left to learn local language because of } \\
\text { the use of technology }\end{array}$ \\
\hline I- 2 & Lampung University (UNILA) & $\begin{array}{l}\text { Using Indonesian when talking to friends directly or } \\
\text { through smartphones. }\end{array}$ \\
\hline
\end{tabular}

Source: Research Result

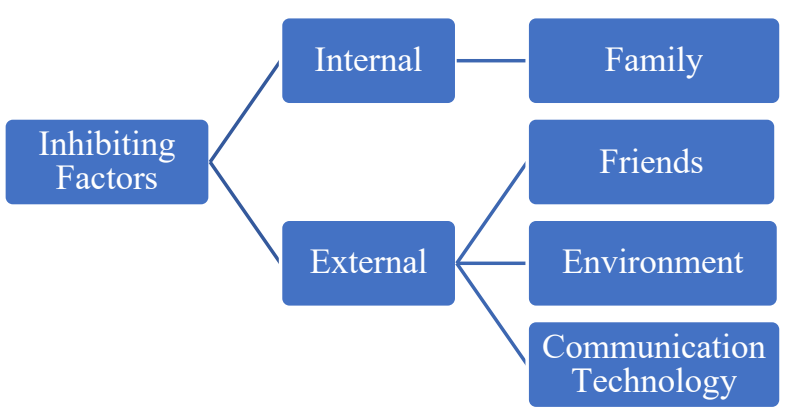

Figure 1. Factors Inhibiting the Teaching and the Use of Local Language (Source: Research Results) 
Local government regulations to discipline the use of local language

Local languages can be introduces through local government policy, such as education system by requiring the use of local languages in the school environment, adding references and having collaborative teachers in providing learning (Akello \& Timmerman, 2017). In addition, environmental factors of family and playmates are the two main factors that are recognized by millennial generation informants about the reasons why it is difficult to use their local language. In addition to these two factors, the weak factor of the local government system in enforcing language rules is also considered to contribute to the decline in the use of local languages. According to millennial generations, the party that can regulate and enforce the discipline of using local languages is the local government. One informant I-5 from University of Indonesia Education stated that language discipline is actually what can make local languages still used, it's just that there are no rules that young people know to regulate about it, the government should make rules so that even though they are forced to use local languages, for example one tribe and one regional language" (Interview with informants on 14/08/2019). This statement is line with the statement of informant I-2 from the University of Lampung that "If there are rules that bind the local language, young people will still speak it". (Informant interview on 3/08/2019). The following statement comes from Informant I-4 from Bina Sarana Informatics University of Jakarta: "regulations can discipline millennials to learn and use regional languages" (Informant interview on 5/08/2019). This statement is emphasized by informant I-11 from State Islamic University (UIN) of Raden Intan Lampung that "regulations made by local governments could force the millennials to speak regional languages" (Informant interview on 2/08/2019). On the other hand, Informant I-6 from Telkom University stated that "I thought (speaking) regional language is only a recommendation, not obligatory because I don't know what the rules are, therefore the rules should be made and socialized (Informant interview on 7/08/2019).

Table 4. Regional Language Regulations

\begin{tabular}{llll}
\hline Informant & \multicolumn{1}{c}{ Origin } & \multicolumn{1}{c}{ Statement } \\
\hline I-5 & $\begin{array}{l}\text { University of Indonesia } \\
\text { Education }\end{array}$ & $\begin{array}{l}\text { Government issues regulations on using regional } \\
\text { language }\end{array}$ \\
\hline I-2 & $\begin{array}{l}\text { University of Lampung } \\
\text { I-4 }\end{array}$ & $\begin{array}{l}\text { Regulations can make the millennials to keep speaking } \\
\text { regional languages }\end{array}$ \\
\hline I-11 & $\begin{array}{l}\text { State Inlamic University (UIN) } \\
\text { of Raden Intan }\end{array}$ & $\begin{array}{l}\text { Regulations can force the millennials to speak regional } \\
\text { language }\end{array}$ \\
\hline I-2 & Telkom University & $\begin{array}{l}\text { Regulations become an evidence that it is obligatory to } \\
\text { speak regional languages }\end{array}$ \\
\hline
\end{tabular}

Source: Research Result Data

The recognition of these millennials is in line with the results of research on the implementation of regional language policies in West Java Province. The results of the study include suggesting that the West Java Provincial Government needs to prepare policies to implement technical regulations, so that policies on regional languages are easily operationalized (Nirmala, 2019). Strict regulations are able to drive millennial generation to use local languages. The strict and binding regulations become concerns of millennial generation so that they are not negligent in learning as well as using local languages.

The system of using local languages has actually been regulated in the Regional Regulation (PERDA) on the use of Indonesian language and the protection of local language and local literatures; however, in the implementation the institution as a leading sector in empowering local 
languages has not optimal in carrying its function. In fact, in several regions, the Regional Language and Arts Development Agency (BPBDK) is no longer functioning. This condition will have a direct effect on knowledge, understanding, and language skills. This situation also threats the regeneration of local language experts, such as local language teachers and language lovers. Therefore, it is necessary to push back the functions of regional institutions that have a role in providing local language teachings. There should be optimization of the role of government elements as leading sectors such as the Office of Culture and Tourism (Disbudpar) and the Regional Language and Arts Development Agency (BPBDK) or similar institutions in each region. The system optimization is expected to be able to encourage local language activists such as school teachers, cultural activists, language activists, and others in teaching local languages in the millennial generation.

Equality communication approach for local language learning

In this part, the informants offered solution regarding the approach they want in learning local language, which is equality communication approach. Equality approach emphasizes seriousness, openness, willingness, and flexibility. These aspects are admitted to be able to build and enhance their motivation in learning and using local languages.

For teaching, especially language, an approach is needed as an art to foster motivation to learn. The same thing was found in previous studies that motivation is needed in the teaching process, although in practice motivation to learn is very dynamic (Akmaliyah et al., 2021) (Kruk, 2016). In the context of this article, the motivation used is the motivation of millennial generation in learning local languages. Motivation with efforts to create an atmosphere of learning and practice using local languages must still be presented.

A conducive atmosphere or environment is expected to be able to restore the interest of millennial generation in the use of local languages. As stated by an informant I-1 from UIN Raden Intan:

"To build motivation and trust from the millennial generation in regional languages, an acceptable communication approach is needed according to which generation the language is taught. Learning regional languages does need seriousness and the right technique in teaching, so teachers need to ask their students what techniques they should combine with hobbies, or have games so that teenagers are interested." (Interview with informant on 7/08/2019).

Informant I-4 added that "millennial generation prefer learning that is democratic and open, and give opportunity for students to discuss how they want to learn, so that we don't feel forced" (Interview with informant on 5/08/2019). This is also confirmed by the informant I-2 from the University of Lampung trying who stated that "It is better to teach the local language in a way that is equivalent to or at the same level as teenagers, therefore open communication is required so that it is easy to accept each other between those who teach and those who learn" (Informant interview on 10/08/2019). "The learning must be flexible and not monotonous, can be done outside the classroom, learning by playing, or watching movies in class so it becomes a dynamic learning" (Informant I-7 interview on 10/08/2019).

The previous statements by the informants show that millennial generation is versatile generation, it means by learning a foreign language, it does not mean millennial generation forgets the local language. Millennials have cultural values such as proficiency in language. Millennials are usually multi-lingual or able to master more than one language (Shofiyyah et al., 2019). It is not hard for millennial generation to learn and master local languages because they were born as 
a versatile generation. They are also known as the generation with full confidence, optimistic, love challenges as well as have high curiosity.

Table 5. Equality Communication Approach in Local Language Learning

\begin{tabular}{lll}
\hline Informant & \multicolumn{1}{c}{ Origin } & \multicolumn{1}{c}{ Statement } \\
\hline I-1 & $\begin{array}{l}\text { State Islamic University (UIN) } \\
\text { of Raden Intan }\end{array}$ & $\begin{array}{l}\text { It takes seriousness and a communication approach that } \\
\text { can be accepted by millennials }\end{array}$ \\
\hline I-4 & $\begin{array}{l}\text { Bina Sarana Informatics } \\
\text { University }\end{array}$ & $\begin{array}{l}\text { A democratic way, invites millennials to be open and } \\
\text { discuss }\end{array}$ \\
\hline I-2 & University of Lampung & Learning is easy and acceptable to millennials \\
\hline I-7 & $\begin{array}{l}\text { University of Informatics and } \\
\text { Business (UNIBI) }\end{array}$ & $\begin{array}{l}\text { Learning must be flexible } \\
\end{array}$
\end{tabular}

Source: Research Result Data

Based on various views on the teaching and use of local languages as a communication tool, the millennials, in addition to suggesting the establishment of a firm local language system, also offer a model of teaching approach called the one tribe one language approach. The approach does not look at the number of tribes, but takes one language from one tribe in each region. According to the informants, the approach does not distinguish between ethnic groups in multiethnic communities. Only one language from the various ethnic groups is recognized as the language of their native language. The approach offered by millennials is relevant to the concept of equality. The concepts commonly used in effective interpersonal communication processes (Hidayat, 2012). The same thing has been proven through several studies that equality can encourage the formation of positive characters such as openness, togetherness, and manners (Suranto, 2014). The equality approach can also build awareness of shared interests (Wulandari; \& Ahmadi, 2015). Equality is also able to accelerate interpersonal relations (Pratiwi \& Sukma, 2013). Teaching with the equality communication approach also involves empathy, which means trying to promote togetherness, rather than personal interests (Yayu et al., 2019). Empathy is the key so that each member in the community group can be open to each other, and accept the importance of using one regional language that is tailored to their place of residence.

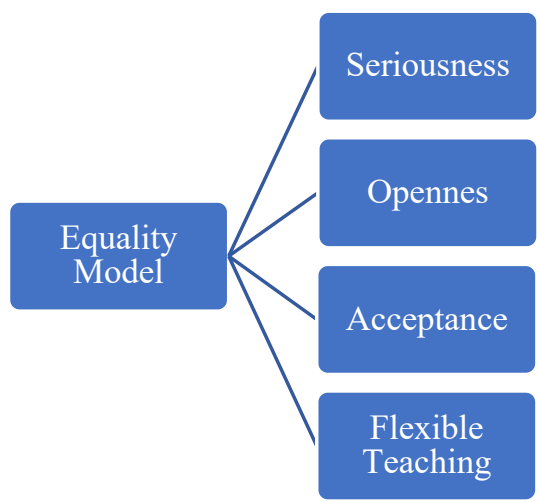

Figure 2. Equality Model in Local Language Learning

(Source: Research Results)

In the context of this paper, equality in question is the similarity in the use of regional languages not for individual identities, but group identities that represent local languages as a 
common language in each region. There is acceptance from each ethnic group member that there is only one regional language that is used in communication as the language of instruction that is the language adapted to the area of residence. For example, in West Java where the people are Sundanese, the language of instruction is Sundanese. Likewise in Lampung Province, the language that must be used as the language of instruction in various contexts is the language of the Lampung region. Central Java Province with its regional language, as well as in East Java, and in other regions.

The concept of equality in the approach of teaching local languages can also be used by local governments in socializing the position of regional languages. Until now local governments have not emphasized and required the use of local languages in various contexts, including local languages as an introduction to education. It must be recognized that currently regional languages are not yet the language of instruction in educational institutions. The equality in language approach is also expected to be able to be an example as well as a binding rule for millennials to learn and use local languages as a communication tool for development in each region. In addition, the existence of a teaching system with an equality approach is able to be one of the solutions in restoring the passion of regional languages ranging from family environment, playmates, school environment, and work environment.

\section{Conclusion}

As a multi-ethnic country, Indonesia also has various cultures. This situation certainly opens up opportunities for changes of new language formation, even forgetting local languages. Multi-ethnic conditions will cause a language shift that is a permanent change in one's choice of language for everyday needs, especially as a result of migration, cultural integration, and globalization. This happens in Indonesia especially in millennial generation. They do not get the local language teaching system due to lack of attention from the family and the weak role and function of the local government.

Millennial generation in Indonesia on average know that they have local languages, but they cannot use them effectively. This condition is affected by the teaching system that has not been optimal, including family, friends, schools, and environment. Almost in all communication contexts today, Indonesian language is preferred as everyday language.

Families should become the foundation for millennial generation in learning cultural values including language; however, families do not set examples to this generation. Likewise, regional government that has the power to build local language teaching system has not yet played an optimal role.

Local language teaching can be done by integrating systems and roles as well as stakeholders. Local government should implement Regional Regulations (PERDA) completely related to the implementation of the obligatory rule of using local languages. The implementation can be managed directly by two institutions as the leading sector at the provincial level, namely the Culture and Tourism Office (Disbudpar) and the Local Language and Arts Development Agency (BPBDK). The two leading sectors must compile including technical rules such as empowerment programs, and preparing human resources. Language empowerment can involve several elements ranging from culture-loving communities, cultural educators, and regional languages, as well as representatives of the community of local language speakers. In addition, local governments can also optimize the existence of the media as channels of information as well as local language documentation. The presence of media, especially digital media, can help millennials in accessing knowledge about local languages. 
Millennial generation offers a solution in the form of equality teaching model, which is a communication approach in local language teaching by determining one language in one region. Although in certain regions there are many languages, but only one regional language applies. However, this approach will not be effective if the local government as a regulator does not try to discipline local language regulations. Therefore, there must be cooperation between local government, leading sectors, and families to jointly foster interest in learning local languages for millennial generation as a communication tool.

The equality teaching model is expected to be able to encourage the interests of millennials to learn and use local languages. The equality model emphasizes the elements of interpersonal communication including sincerity, openness, and acceptance of the values that apply in each region, including the value of using local languages. The equality model emphasizes one regional language as a shared identity within the community. In each region, of course there are various tribes that gave birth to many languages. Therefore, it is hoped that differences in ethnicity do not mean the language used must also be different. However, there must be seriousness to accept the use of one language that is adapted to where one resides.

Declaration of conflicting interest

The authors declared no potential conflicts of interest in this work concerning the research, authorship, and publication of this article.

Funding acknowledgement

This research received no external funding.

\section{References}

Agustin, Y. (2011). Kedudukan Bahasa Inggris Sebagai Bahasa Pengantar Dalam Dunia Pendidikan. Deiksis, 03(04), 354-364.

Akello, L. D., \& Timmerman, M. C. G. (2017). Local language a medium of instruction: challenges and way forward. Educational Action Research, 0792(May), 1-19. https://doi.org/10.1080/09650792.2017.1319287

Akmaliyah, A., Hudzaifah, Y., Ulfah, N., \& Pamungkas, M. I. (2021). Child-Friendly Teaching Approach for Arabic Language in Indonesian Islamic Boarding School. International Journal of Language Education, 5(1), 501. https://doi.org/10.26858/ijole.v5i1.15297

Anwar, S., \& Salim, A. (2018). Pendidikan Islam dalam Membangun Karakter Bangsa di Era Milenial. Altadzkiyyah:Jurnal Pendidikan Islam, 9(2), 233-247.

Arsanti, M. (2014). Pemerolehan Bahasa Pada Anak (Kajian Psikolinguistik). Jurnal Pendidikan Bahasa Indonesia, 3(2), 24-47. https://s3.amazonaws.com/academia.edu.documents/61003069/3959t_PEMEROLEHAN _BAHASA_PADA_ANAK20191024-9010-atrcwo.pdf?response-contentdisposition $=$ inline $\% 3 \mathrm{~B}$ filename\%3DT PEMEROLEHAN BAHASA PADA ANAK.pdf\&X-AmzAlgorithm=AWS4-HMAC-SHA256\&X-Amz-Credential=AKI

Barni, M. (2019). Tantangan Pendidian di Era Milenial. Jurnal Teansformatif, 3(1), 99-116. Denzin, N. K., \& Lincoln, Y. S. (2009). Handbook of Qualitative Research. Pustaka Pelajar. Habibi, M. (2018). Optimalisasi Dakwah Melalui Media Sosial Pada Era Milenial. Al-Hikmah, 12(1), 101-116. https://doi.org/10.24260/al-hikmah.v12i1.1085

Hidayat, A. (2018). Metode Pendidikan Islam Untuk Generasi Millennial. FENOMENA: Jurnal 
Penelitian, 10(1), 55-76.

Hidayat, D. (2012). Komunikasi Antarpribadi dan Medianya. Graha Ilmu.

Hidayat, D., \& Hafiar, H. (2019). Nilai-nilai budaya soméah pada perilaku komunikasi masyarakat Suku Sunda. Jurnal Kajian Komunikasi, 7(1), 84-96.

Hidayat, D., Kuswarno, E., Zubair, F., \& Hafiar, H. (2017). Negosiasi Citra Budaya Masyarakat Multikultural. ASPIKOM, 3(2), 157-172.

Hidayat, D., Kuswarno, E., Zubair, F., \& Hafiar, H. (2018). Public Relations Communication Behavior Through a Local-Wisdom Approach: The Findings of Public Relations Components Via Ethnography as Methodology. Malaysian Journal of Communication, 34(3), 56-72.

Humaera, I. (2015). Inhibition In Speaking Performance. Journal of The Association for Arabic and English, 1(1), 31-50. https://media.neliti.com/media/publications/223638-inhibition-inspeaking-performance.pdf

Indira, D., Muhtadin, T., \& Djajasudarma, T. F. (2018). Fiksimini Berbahasa Sunda dalam Media Sosial (Sundanese Minifiction in Social Media). Jurnal Komunikasi, Malaysian Journal of Communication, 34(2), 293-308. https://doi.org/10.17576/jkmjc-2018-3402-18

Indriati, I. (2015). Do You Care Your Local Language? Journal on English as a Foreign Language, 4(2), 55. https://doi.org/10.23971/jefl.v4i2.75

Jandt, F. E. (2013). An Introduction to Intercultural Communication; Identities in a Global Cummunity. SAGE Publication.

Kruk, M. (2016). Language Teaching Research Temporal fluctuations in foreign language motivation: Results of a longitudinal study. 4(May), 1-17.

Laila, W. N. (2016). Konsep Diri Remaja Muslim Pengguna Bahasa Jawa Krama. Profetik: Jurnal Komunikasi, 9(2), 61. https://doi.org/10.14421/pjk.v9i2.1206

Maifianti, K. ., Sarwoprasodjo, \& Susanto. (2014). Komunikasi Ritual Kanuri Blang sebagai Bentuk Kebersamaan Masyarakat Tani Kecamatan Samatiga Kabupaten Aceh Barat Provinsi Aceh. Jurnal Komunikasi Pembangunan, 12(2), 1-6.

Mohammad, S., Adel, R., Davoudi, M., \& Ramezanzadeh, A. (2016). Language Teaching Research A qualitative study of politeness strategies used by Iranian EFL learners in a class blog. Iranian Journal of Language Teaching Research, 4(1), 47-62.

Nirmala, S. (2019). Rezim-tidak-berpihak-pada-bahasa-daerah. Pikiran Rakyat. https://www.pikiran-rakyat.com/pendidikan/2019/02/28/rezim-tidak-berpihak-padabahasa-daerah

Pastika, I. (2012). Pengaruh Bahasa Asing terhadap Bahasa Indonesia dan Bahasa Daerah: Peluang atau Ancaman? Jurnal Kajian Bali (Journal of Bali Studies), 2(2), 141-164.

Pratiwi, S. W., \& Sukma, D. (2013). Komunikasi Interpersonal Antar Siswa Di Sekolah Dan Implikasinya Terhadap Pelayanan Bimbingan Dan Konseling. Konselor, 2(1), 324-329. https://doi.org/10.24036/02013211268-0-00

Rustipa, K. (2013). Local Language as a Means to Build Tolarable Community in Indonesia. Dinamika Bahasa Dan Ilmu Budaya, 8(2), 58-70.

Samovar, L. A., Porter, R. E., \& McDaniel, E. R. (2010). Komunikasi Lintas Budaya; Communication Between Cultures (7th ed.). Salemba Humanika. http://www.penerbitsalemba.com

Sari, D. E. (2019). Quizlet: Aplikasi Pembelajaran Berbasis Smartphone Era Generasi Milenial. Jurnal Pendidikan Dan Ilmu Sosial, 29(1), 9-15.

Shofiyyah, N. A., Ali, H., \& Sastraatmadja, N. (2019). Model Pondok Pesantren di Era Milenial. 
BELAJEA: Jurnal Pendidikan Islam, 4(1), 1. https://doi.org/10.29240/belajea.v4i1.585

Suranto. (2014). Integrasi Pendidikan Karakter Dalam Pembelajaran Mata Kuliah Komunikasi Interpersonal. Jurnal Pendidikan Karakter, 4(3), 225-234. https://doi.org/10.21831/jpk.v0i3.5586

Sutijono, S., \& Farid, D. A. M. (2018). Cyber Counseling di Era Generasi Milenial. Sosiohumanika, 11(1), 19-32.

Tondo, F. H. (2009). Kepunahan Bahasa-Bahasa Daerah: Faktor Penyebab Dan Implikasi Etnolinguistis. Jurnal Masyarakat \& Budaya, 11(2), 277-296.

Vera, N., \& Wihardi, D. (2012). "Jagongan” Sebagai Bentuk Komunikasi Sosial Pada Masyarakat Solo dan Manfaatnya Bagi Pembangunan Daerah. Jurnal Komunikasi MAKNA, 2(2), 58-64.

Wulandari;, R., \& Ahmadi, D. (2015). Komunikasi Antarpribadi Orangtua dan Anak dalam Penggunaan Gadget. Prosiding Penelitian SPeSIA Unisba, 341-247. http://karyailmiah.unisba.ac.id/index.php/humas/article/download/2161/603

Yayu, N., Hidayat, D., \& Suhadi, M. (2019). Pendekatan intercultural communication pada public relations PT Santos dalam membangun komunikasi empati. Jurnal Profesi Humas Universitas Padjadjaran, 4(1), 1-22. 